\title{
Agnieszka Chłosta-Sikorska, Kraków i jego mieszkańcy w latach 1945-1947, Wydawnictwo Libron - Filip Lohner, Kraków 2016, pp. 376.
}

Krakow 'survived' the war, however, the city was very seriously affected by it. As the capital city of Generalgouvernement, it was, in many ways, a peculiar city, which affected inhabitants of Krakow during the German occupation, but also for a certain period after it ended. The inhabitants of the city, who tried to recover from the nightmare of the war, had to face new, communist reality, which, in many aspects, was not better from what they experienced a few years earlier at all. In general, it was a certain process, which lasted up to dozen or so years and was characterized by the introduction of totalitarianism and, up to a certain point in time, militarization of social life. Agnieszka Chłosta-Sikorska tried to outline that problem.

The Author has a professional connection with the Pedagogical University of Krakow and the reviewed work was based on the doctoral dissertation titled: Życie codzienne w Krakowie w latach 1945-1947, defended at the University she currently is professionally tied to (at that time: Pedagogical Academy of Commission of National Education in Krakow). However, the published work is significantly better than the original version, both as regards the volume and the subject matter. The new work is also more advanced in respect of the techniques used and the way of narrating. It is, for sure, the evidence of the constant scientific development of the Author. The title of the work was changed for a reason - the 'everyday life of' the inhabitants of Krakow takes up less than half of the reviewed publication, the rest concerns widely understood political, social and economic issues.

The source base of the work is extensive and, in my opinion, sufficient. As regards the archive materials, the Author used those deposited in the Archives of Modern Records in Warsaw, National Archives in Krakow, Institute of National Remembrance in Krakow, Archives of the Metropolitan Curia in Krakow, Archive of the Jagiellonian University, Archive of the Pedagogical University of Krakow and the Archive of the Centre of Documentation of Deportations, Expulsions and Relocations attached to that university. She used numerous printed sources and press 
titles from the years 1945-1947. As regards the section 5 of the references, titled Opracowania, pamiętniki, relacje, wspomnienia [Studies, diaries, reports, memories], it must be underlined that the last three positions are printed sources and they cannot be set together with the compilations, the significant number of which was also used in the work.

The beginning and the end of the period discussed in the work and selected by the Author, are to a certain extent problematic. On one hand, it is understood that A. Chłosta-Sikorska wanted to present the image of the society of Krakow as a city recovering from the consequences of the war for the first two years following the occupation and to underline how the experiences of war influenced the inhabitants. On the other hand, the justification of the choice of these two points in time by the Author raises serious doubts. She states that they are two key points in time in the history of the city. In 1945, the German occupation of Krakow ended, which was related to the dreams of new, free Poland. [...] While the year 1947, to a certain extent, put an end to those delusions. The new system, supported by external forces, finalized the creation of the foundations of the new $\operatorname{order}^{11}$ (p. 11). While the first point in time is completely obvious and justified, the second one is not. The Author justified it by citing the findings of the outstanding researcher, Krystyna Kersten, who stated that 'in the year 1947, the first stage of the Stalinization of the state was completed and, for this reason, the reflections included in this book concern only the period preceding that date ${ }^{2}$ (p. 12). However, it should be strongly underlined that the statements of $\mathrm{K}$. Kersten concern in this case the entire country, while the discussed aspects in the particular cities differed, not entirely in parallel with the periodization of the consolidation of the communist system in Poland, as regards the central level authorities. Therefore, the basic question in this case is whether the periodization of the history of Krakow of 1945-1989 is identical to the one of the entire Poland? In my opinion, it is not, because, like during the Second World War, although in a different context, the discussed city remained unique in its own way during the Polish People's Republic [hereinafter: PPR] era. Andrzej Chwalba, on whose findings - but not in the case of periodization of the history of Krakow - the Author also bases her work, underlines that

1 'są to dwie kluczowe cezury w historii miasta. Rok 1945 przynosi wyjście Krakowa z hitlerowskiej okupacji, co wiąże się z marzeniami o nowej, wolnej Polsce. [...] Natomiast rok 1947 przyniósł w pewnej mierze koniec złudzeń. Nowy system, wspierany z zewnątrz, sfinalizował tworzenie fundamentów nowego porządku'.

2 'w roku 1947 zakończył się pierwszy etap stalinizacji kraju i dlatego też na tej dacie zostały zakończone podjęte w książce rozważania'. 
the symbol of Sovietization of Krakow was the presence of the Soviet instructors and activists of apparatus of repression, operating in this city until the October $1956^{3}$ - and I believe this is the date constituting the point in time when the intense communization of the city ended. That was the period called, in the later PPR historiography, the 'period of consolidation of the people's authorities's. Andrzej Chwalba, in his fifth volume on history of Krakow, states that the event that definitively ended the period of transformation of Poland into a satellite state was the elections that took place on 19 January $1947^{5}$. However, he also refers to Poland as a whole and not to Krakow; the completion of the Poland 'satellization' process did not have to result also in the completion of the processes of introducing totalitarianism and communization, which were gradual. The time frameworks, specified by the Author, cover a very short period and, in my opinion, they should be rather be discussed in an article, not in a more extensive monograph. It is worth noticing that A. Chłosta-Sikorska wrote such article and published it in 'Krakowskie Studia Małopolskie' in $2012^{6}$, and the first chapters of the reviewed work constitute generally an extension of the article. I am surprised that she did not include the abovementioned publication in the references.

Prof. Chwalba made also an interesting observation that Krakow, de facto, has never been completely Sovietized, remaining, until the end of PPR era, one of the main opposition centers in Poland. I do not criticize the Author for the selection of wrong time frameworks for her work, but I do criticize her for the failure to justify them in a factual manner. In fact, the year 1947 could constitute for the inhabitants of Krakow the 'end of delusions', but it was not, for sure, the end of Stalinization, it was not even the end of its first stage. I believe that, also in respect of Krakow, the period: 1944-1956 should be evaluated as a whole, because too many significant events took place later, after 1947, and these events were, as a matter of fact, connected in a significant way with those of the years 1945-1947. The fragmentation and selection of more narrow frameworks may, in this case, result in the failure to present the issues in a complete manner, which could make it impossible for the reader to understand them and, to some extent, present the issues in an insubstantial manner. In her work the Author addresses also topics as cultural life, school system,

\footnotetext{
3 A. Chwalba, Okupacyjny Kraków w latach 1939-1945, Kraków 2011, p. 563.

4 'okresem umacniania władzy ludowej'; or the broader discussion of the subject, see: M. Czyżniewski, Propaganda polityczna władzy ludowej w Polsce 1944-1956, Torun 2005.

5 A. Chwalba, Dzieje Krakowa, vol. 6, Kraków w latach 1945-1989, Kraków 2004, p. 179.

6 See: A. Chłosta-Sikorska, Wychodzenie z wojny. Kraków 1945-1947, 'Krakowskie Studia Małopolskie' 2012, 17, pp. 98-111.
} 
media development or the way of spending free time by the inhabitants of Krakow. The two year period is, in my opinion, too short, to reliably present these issues.

The work consists of Introduction, seven basic chapters and ending. The 1st chapter covers the topic of monopolization of power by the Polish United Workers' Party in Poland and Krakow, including the issues of functioning of the Underground State in the discussed city. The 2nd chapter presents the social and economic transformations in Krakow. The 3rd chapter is dedicated to the first parliamentary elections after 1945 and the widely defined 'democracy farce' of that time and - it is difficult to understand, why, considering other topics - the situation of the Catholic Church. The 4th chapter was dedicated to the cultural life in Krakow and the 'entertaining' ways to spend free time of the inhabitants of that city. The 5th chapter describes the radio and press in Krakow during the discussed period, the 6th - the education and scientific life, while the last one, the 7th, was dedicated to the question of combined plants and the development of the plan of construction of Lenin Steelworks.

If I had been in the position of the Author, I would have discussed the situation of the Catholic Church and the religious life of the inhabitants of Krakow more extensively, dedicating an entire separate chapter to that issue. Either way, these questions, addressed by the Author, take up, all together, dozen or so, up to few dozen of pages. Especially cardinal Sapieha, Krakow metropolitan, who enjoyed great authority and whom both German authorities and communists authorities failed to break (he was named, for this reason, the Invincible Prince - the Author should have used capital letter in the case of that term), was a very interesting person. In my opinion, the Author's having included the 5th chapter, consisting only of a few pages, in the work, completely misses the mark and it should be combined, as a subchapter, with the chapter four or two.

The war experiences, which is obvious, strongly influenced the inhabitants of Krakow. The Author wrote about 'paralysed and terrified' people, while the society was 'broken and devastated' (p. 25) to such an extent that various deviant behaviors and suicides took place. Despite that situation, 'Krakow preserved its historical structure and urban fabric, which developed, in general, in the 19th century'7 (p. 82). It was described well by an eye-witness, Leszek Gaszczyński: 'As every inhabitant of Warsaw, while visiting Krakow, unaffected by the war, I feel as if it was still spring

7 'Kraków zachował swój historyczny układ i tkankę miejską wykształconą zasadniczo w XIX wieku'. 
$1939^{\prime 8}$ (p. 76). However, the society of Krakow was not 'złamane' enough to succumb to the communist agitation, as compared to the German occupation period, when the Nazi propaganda, in many cases, had the results the occupier expected.

A. Chłosta-Sikorska decided to present the attitude of the Soviet army towards the Polish civilians, as well as to the territory it occupied and where it promptly commenced 'sharing the spoils'. The Author underlined that the 'soldiers of the Red Army terrified the civilians. They felt they can do whatever they want, they 'freed' many Poles from clothes, jewelry and other things ${ }^{\prime 9}$ (p. 29). She wrote that the western part of the city, which, before the year 1945, was called the German part, "was inhabited by the employees of the new security apparatus and the functionaries of authorities' ${ }^{10}$. She quotes the personal reflection of Andrzej Chwalba on this topic, who states that it was a 'clear sign that a new era has started"11 (p. 32). As the Author underlines: 'To the inhabitants of Krakow, the unrestricted power and overt violations of the prewar standards left no doubt and meant the beginnings of the new subjugation $^{\prime 2}$ (p. 35). Therefore, it seems that she does not have doubts that since 1945, de facto, a new occupation of Poland has been taking place. What is interesting, a different stance is presented by the promoter of the work on the basis of which the reviewed book was created, Jacek Chrobaczyński ${ }^{13}$ and it is a pity that A. Chłosta-Sikorska did not try to discuss the arguments presented by him and to present the arguments to support her own thesis. Wiesław Wysocki, the historian of the Cardinal Stefan Wyszyński University in Warsaw, frequently emphasized during his lectures that the Soviet Union was, in reality, a new occupier of Poland, which was, in a way, symbolized by the transformation of the German concentration camps into Soviet ones after the war. In this context, the

8 ‘Jak każdy Warszawiak w nietkniętym wojną Krakowie doznaję wrażenia, jakby czas zatrzymał się tu na wiośnie roku 1939'.

9 'żołnierze Armii Czerwonej byli postrachem dla ludności cywilnej. Czuli się całkowicie bezkarni, niejednego Polaka 'wyzwolili' z ubrania, biżuterii i innych rzeczy'.

10 'została zasiedlona przez pracowników nowego aparatu bezpieczeństwa oraz funkcjonariuszy władzy'.

11 'czytelny znak nowego czasu'.

12 'dla krakowian wszechwładza oraz jawne łamanie przedwojennych standardów nie pozostawiały złudzeń i oznaczały początki nowego zniewolenia'.

${ }^{13}$ Jacek Chrobaczyński is outraged by e.g. the use of the term: 'druga okupacja sowiecka' ['second Soviet occupation'], as he believed it has never happened. See: J. Chrobaczyński, Czy Polacy zostali rzeczywiście zniewoleni przez komunistów po II wojnie światowej? Kilka uwag do problemu, in: Skrwawione dusze. Prawda. Sprawiedliwość. Przebaczenie. Pojednanie, ed. A. Bartuś, Oświęcim 2015, pp. 53-84. 
stance of J. Chrobaczyński is rather eccentric. I believe that this remark is adequate, especially taking into consideration that the Author quotes as many as six compilations dedicated to the German occupation of Krakow, the Author of which is J. Chrobaczyński I have already mentioned and, as she underlined herself: 'the western part of the city, which, during occupation period, was called the German district, was inhabited by the employees of the new security apparatus and the functionaries of authorities $^{\prime 14}$ (p. 32). It was a characteristic and symptomatic sign of the former occupier being replaced by the new one.

The Author of the reviewed work compares sometimes, as a matter of fact, the totalitarian subjugation by the Soviet Union with the German occupation that hasjustended. Writing about theactivities of thecommander colonel Wasilij Fiedosienko, she underlined that the regulations he issued were sometimes similar to those issued during the German occupation (p. 32). A similar analogies were present also in respect of the religious practices that 'were gradually becoming an opportunity to protest against the imposed political system. The song 'Boże coś Polskę' ended with the following words (like during the German occupation): please, Lord, return us free fatherland $d^{15}$ (pp. 149-150). It is a pity that the Author did not carry out a comparative study examining the religious life of the inhabitants of Krakow during the war and in the time immediately following it.

Continuing the discussion of the issues related to religion, I would like to point out a strange statement of the Author: 'the communist ideology, in line with the ideas of Karl Marx and Vladimir Lenin assumed, however, a world without the God. We can perceive it as a peculiar example of practical philosophical dualism: while, according to the ideology, God did not exist, it fought against Him and was systematically pointing out that religion is Opium des Volkes' ${ }^{16}$ (p. 148). I notice an ontological error in this eclectic and logically inconsistent statement. After all, the communist authorities did not fight against God, who, according to them, did not exist (there were exceptions to that rule), but the phenomenon of faith and all its manifestations. However, in the writings of the communist thinkers,

14 'zachodnia część miasta, zwana w okresie okupacji dzielnicą niemiecka, została zasiedlona przez pracowników nowego aparatu bezpieczeństwa oraz funkcjonariuszy władzy'.

15 'z czasem stawały się także okazją do zamanifestowania sprzeciwu wobec narzuconego ustroju. Śpiew pieśni Boże coś Polskę kończył się słowami, jak za okupacji niemieckiej ojczyznę wolna, racz nam wrócić Panie'.

16 'ideologia komunistyczna, podążając tropem Karola Marksa oraz Włodzimierza Lenina zakładała jednak świat bez Boga. Można to uznać za swoisty przykład dualizmu filozoficznego praktycznego: nie uznając Boga, jednocześnie z nim walczyła i systematycznie wykazywała że religia to Opium des Volkes'. 
in particular Lenin, one can notice certain ambivalent conclusions, concerning the freedom of conscience and, at the same time the necessity to fight against the 'opium of the people', that is religion. If A. ChłostaSikorska had included that motif in her reflections, I would not have had any reservations. I would not also have had any reservations if 'militant atheism' had not been an element of the Marxist ideology, cherished by the Polish communist politicians. In this case, nonetheless, I cannot agree with the Author.

However, A. Chłosta-Sikorska openly states that the authorities did not fight Church in the period immediately following the war (p. 158). It was probably one of the reasons why archbishop Adam Sapieha, until his death, remained untouchable for the communists. The Author states that 'many Greek Catholics converted to the Orthodoxy in order to be able to continue celebrating their faith in accordance with the rite ${ }^{\prime 17}$ (p. 165). However, the term 'rite' is applied to the internal liturgical factions of a particular Church, whether it is the Catholic Church (mostly Eastern Catholic Churches) or the Orthodox Church, for this reason, these factions of Christianity may not be considered together and they cannot be discussed generally as 'eastern rite'.

The Author quotes the following fragment of a popular book of Michał Rożek titled: Kraków. Przewodnik historyczny: 'the legend about the maneuver that saved Krakow, fabricated by the communists, is an ordinary lie. Germans have never planned to destroy the monuments of Krakow'18 (p. 73). It is a reference to the legend of the PPR era about the Soviet army that, with a quick maneuver, saved Krakow from destruction. The same Author, quoted by the Author of the reviewed work, in his other book described another legend, according to which the archbishop Adam Sapieha, thanks to the diplomatic efforts, convinced Stalin not to carry out activities that could result in the destruction of Krakow ${ }^{19}$. It is a pity that the Author did not refer to that legend and did not try to verify the truthfulness of that history. $\mathrm{He}$ mentions the 'Invincible Prince' frequently in his book and the authority of the archbishop is confirmed by the fact that the officers of the Home Army [Armia Krajowa] sought his advice (p. 54); moreover, the Security Office [Urząd Bezpieczeństwa] gathered information about him (p. 157).

The Author mentions on the p. 160 that the inhabitants of Krakow

17 'wielu krakowskich grekokatolików wybrało przejście na prawosławie, aby pozostać w obrządku'.

18 'spreparowana na użytek komunistyczny legenda o manewrze, który ocalił Kraków, jest zwykłym przekłamaniem. Niemcy nigdy nie planowali zniszczenia zabytków Krakowa'.

19 M. Rożek, Kardynał Sapieha, Kraków 2007. 
were concluding marriages, however, that statistics on the conclusion of marriages were not compared to the statistics describing the phenomenon gathered during the time of war. The war could not have affected those proportions, therefore the number of the concluded marriages in Krakow in the years 1939-1945 remained the same as in the interwar period ${ }^{20}$. What is interesting - and what was correctly pointed out by A. Chłosta-Sikorska - a marriage had a sacral nature for the inhabitants of Krakow; the efforts of the communist authorities, aimed at making it a secular event under the aegis of a state clerk failed, despite a large scale atheist propaganda.

A. Chłosta-Sikorska states that 'some inhabitants of Krakow believed that Jews are supporters of the new political system and act to the detriment of Poland $[\ldots]$. Those statements were false ${ }^{21}$ (p. 167). The stereotype related to the phenomenon of the so-called 'Judeo-Communism' is for sure unfair to many Jews, however, it does not mean that many Jews did not support the new political system in the post-war Poland. If the Author contests the significant participation of Jews in the activities of the Security Office and the significant number of Jews holding managerial positions in the state institutions in the PPR era, questioning the results of the research of the historians such as e.g. Krzysztof Szwagrzyk, Marek Chodakiewicz or Jan Żaryn, I would be very grateful if she presented the results of her own query concerning that topic. The Author does not discuss these issues in any way, we also do not know whether she is aware of them, she only sums up her short digression with an enigmatic and not entirely true statement that 'those statements were false' ${ }^{22}$. The shortcomings of this kind constitute, in my belief, a benefit to the German politics of memory, which sometimes presents as the only reason of the emigration of Jews from Poland, after the Second World War, the Poles and their - frequently created in the imagination of a historian - spiteful antisemitism. It is a pity that A. Chłosta Sikorska did not refer, as regards this issue, to the book on the Extermination of the Krakow Jews, which was written by researchers: Andrea Löw and Markus Roth ${ }^{23}$. The above-mentioned German authors point out the antisemitism of Poles as the 'direct cause'24 of emigration of Israelites from our country. The anti-Jewish riots in the era of the PPR, usually motivated by the central authorities and taking place under

20 A. Czocher, Życie religijne wiernych Kościoła rzymskokatolickiego w Krakowie w latach 1939-1945, in: Kościót krakowski 1939-1945, ed. Ł. Klimek, Kraków 2014, p. 77.

21 'niektórzy krakowianie twierdzili, że Żydzi są zwolennikami nowego ustroju oraz działają na szkodę Polski [...]. Były to stwierdzenia fałszywe'.

22 'były to stwierdzenia fałszywe'.

23 A. Löw, M. Roth, Krakowscy Żydzi pod okupacją niemiecką 1939-1945, Kraków 2014.

24 'bezpośrednią przyczyną'. 
supervision of the eastern 'Big Brother' definitely were not the only reason of emigration of Jews from our country.

I believe that the 'new occupation' in Krakow was much more dramatic than the presentation of the Author suggests. As Soviets were gang raping the Krakow women and girls, also at Kraków Główny railway station (the Author did not mention it) and shooting intervening Poles, and as the Polish authorities wrote a protest letter to Stalin himself in connection with licentiousness and brutality of their 'liberators', perfunctory mentions of plunders and robberies of the above-mentioned soldiers seem like a drop in the ocean. The picture of the hell the inhabitants of Krakow were through, in the book of Chłosta-Sikorska, is incomplete and only fragmentary, while it should be presented in a thorough manner and as extensively as possible, taking into consideration the narrow time frameworks of the book. And it should not be overshadowed by the sentimental image of 'happy' inhabitants of Krakow, spending free time in a cinema or theater - the Author dedicated surprisingly large part of her work to his issues.

The language of the book of Agnieszka-Chłosta Sikorska is very accessible, which makes it very easy and pleasant to read. The book has its drawbacks, but it is a valuable source of information, which can be recommended the persons interested in the history of Krakow, but also widely defined history of everyday life. I hope that the reviewed work will be reissued and supplemented, and the Author, in addition to the main direction of her research (the history of women and the didactics of history), will focus also, to some extent, on the regionalistic research, which has always been of high quality at her home university. 


\section{REFERENCES}

Chłosta-Sikorska A., Wychodzenie z wojny. Kraków 1945-1947, ‘Krakowskie Studia Małopolskie' 2012, 17.

Chrobaczyński J., Czy Polacy zostali rzeczywiście zniewoleni przez komunistów po II wojnie światowej? Kilka uwag do problemu, in: Skrwawione dusze. Prawda. Sprawiedliwość. Przebaczenie. Pojednanie, ed. A. Bartuś, Oświęcim 2015.

Chwalba A., Dzieje Krakowa, vol. 6, Kraków w latach 1945-1989, Kraków 2004.

Chwalba A., Okupacyjny Kraków w latach 1939-1945, Kraków 2011.

Czocher A., Życie religijne wiernych Kościoła rzymskokatolickiego w Krakowie w latach 19391945, in: Kościół krakowski 1939-1945, ed. Ł. Klimek, Kraków 2014.

Czyżniewski M., Propaganda polityczna władzy ludowej w Polsce 1944-1956, Toruń 2005.

Löw A., Roth M., Krakowscy Żydzi pod okupacja niemiecka 1939-1945, Kraków 2014.

Rożek M., Kardynat Sapieha, Kraków 2007.

Przemysław Sołga

(Pedagogical University of Krakow) https://orcid.org/0000-0002-0670-8857

E-mail: przemyslaw.solga@gmail.com

\begin{tabular}{|l|l|l|l|}
\hline \multicolumn{2}{|l|}{ PUBLICATION INFO } \\
\hline
\end{tabular}

